\title{
Lethal osteogenesis imperfecta associated with 46,XY,inv(7)(p13q22) karyotype
}

\author{
A S KNISELY* $\dagger$, A RICHARDSON†, D ABUELO \\ AND D B SINGER*†
}

*Program in Developmental Pathology, Division of Biology and Medicine, Box G-WI, Brown University, Providence, Rhode Island 02912; †Department of Pathology and Laboratory Medicine, Women \& Infants' Hospital of Rhode Island, 101 Dudley Street, Providence, Rhode Island 02905; and $\ddagger$ Department of Pediatrics, Rhode Island Hospital, 593 Eddy Street, Providence, Rhode Island 02905, USA.

SUMmaRY An infant who died of complications of osteogenesis imperfecta (OI) at 22 days of age had a $46, X Y, \operatorname{inv}(7)(\mathrm{p} 13 \mathrm{q} 22)$ karyotype. His mother carried the same inversion. One breakpoint of the inversion was within the region of the gene for $\alpha 2(\mathrm{I})$ procollagen. The product of this gene is a component of type I collagen, the principal collagen synthesised by osteoblasts. Karyotypic abnormalities involving type I collagen gene sites have not previously been reported in association with $\mathrm{OI}$.

\section{Case report}

A 24 year old, gravida 2 woman presented in the 26th week by dates of gestation for sonographic evaluation of fetal age. The limbs of the fetus were shortened and bowed and the thoracic diameter was decreased. Short limbed dwarfism was diagnosed. Labour began spontaneously at 38 weeks and a caesarean section was performed. The limbs of the infant (fig 1), a male, were severely deformed. Caput membranaceum was present. The facies was rounded, with a fine, pointed nose, and the sclerae were white. Other findings included a single transverse palmar crease on the left and a complexly abnormal palmar pattern on the right (fig 1 ). $X$ rays showed a radiolucent skull and spine, beaded, irregular ribs, and thick, crumpled long bones (fig 2). Osteogenesis imperfecta (OI) was diagnosed. Supportive care without oxygen supplementation or ventilatory assistance was provided. The infant died at 22 days of age after several hours of tachypnoea with increasing cyanosis. Necropsy showed many rib fractures that bowed the chest wall inward. The lungs weighed $48 \mathrm{~g}$ (expected normal weight $65 \pm 17$ $\mathrm{g}^{1}$ ). No pneumonia was found. Death was attributed to respiratory insufficiency owing to pulmonary hypoplasia, possibly aggravated by chest wall instability. Fibroblasts cultured at necropsy did not grow.

Received for publication 29 January 1987.

Revised version accepted for publication 18 May 1987.
Both parents, recent immigrants from the same town in the Cape Verde islands, were of black

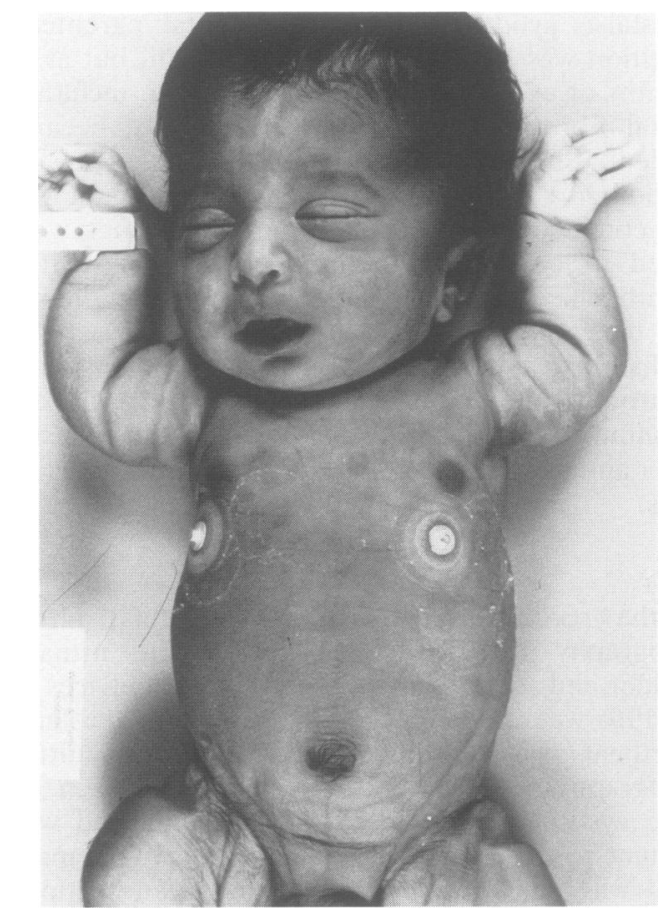

FIG 1(a) Photograph of face and anterior torso. The habitus is that frequently encountered in lethal osteogenesis imperfecta. 


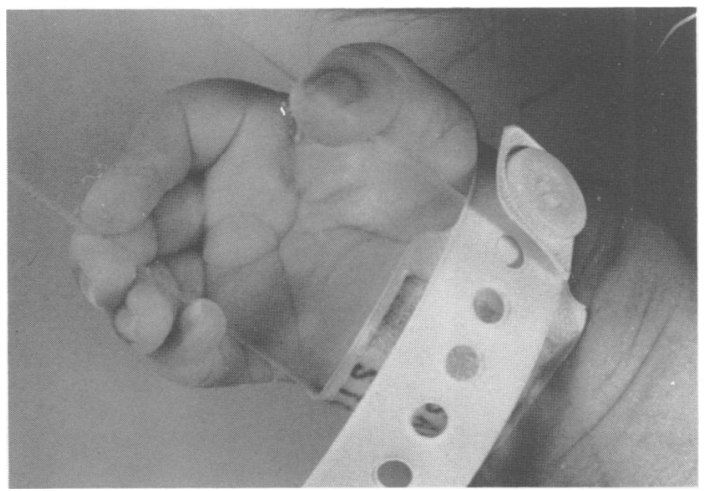

FIG 1(b) Photograph of right palm. The crease pattern is complexly abnormal.
Portuguese background; consanguinity was denied. Their first child, a male, was three years old and well. None had signs or symptoms of OI. All had normal palmar crease patterns. No history could be obtained of osteochondrodystrophy in the family of either parent.

Giemsa banded preparations of cultured peripheral blood lymphocytes from the infant showed a $46, X Y$, inv(7) karyotype. The inversion was pericentric with breakpoints at p13 and q22 (fig 3). Similar preparations of peripheral blood lymphocytes from the mother showed a $46, X X, \operatorname{inv}(7)(p 13 q 22)$ karyotype. Preparations from the father showed no chromosomal abnormalities. Permission to draw blood from the sib was refused. No other family members were available for study.

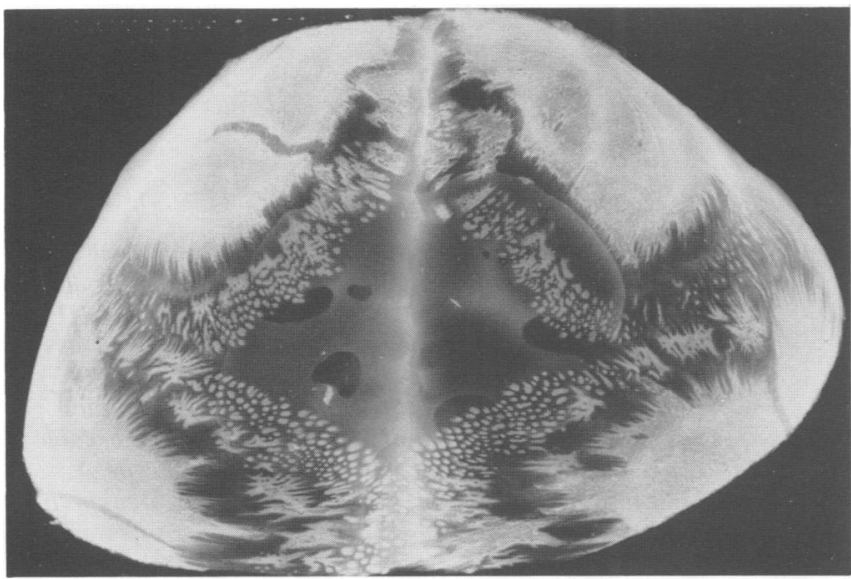

FIG 2(a) Radiograph (mammography technique) of anterior portion of membranaceous calvarium, showing innumerable minute Wormian bones.

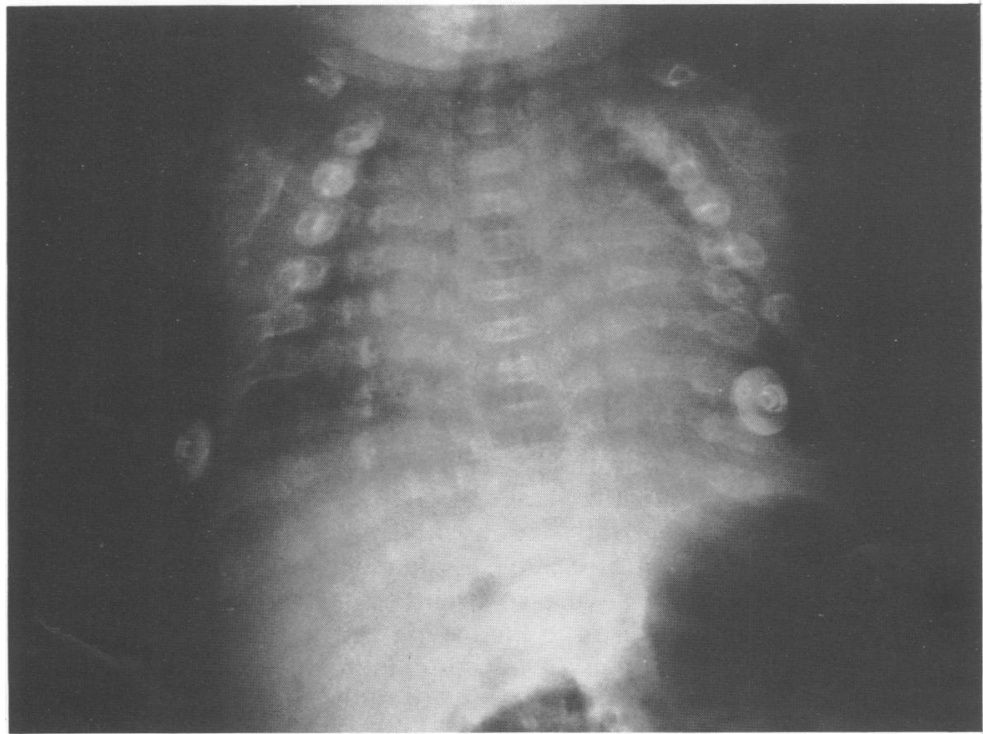

FIG 2(b) Radiograph of chest.

The ribs are broad and show many fractures. 


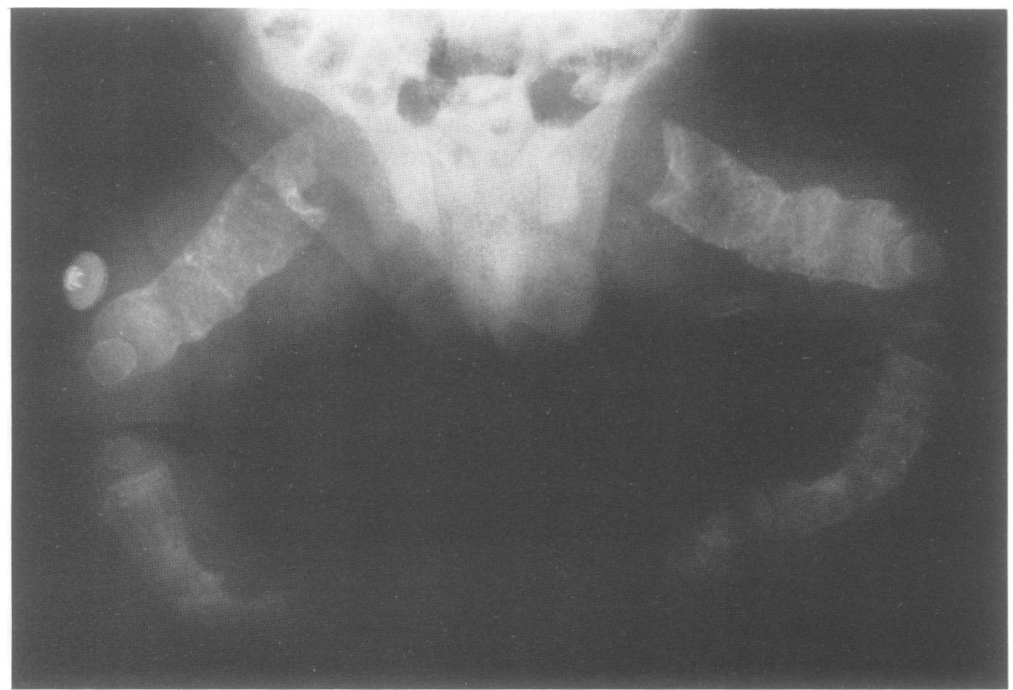

FIG 2(c) Radiograph of pelvis, legs, and feet. The multiple fracture sites and resultant deformities are evident.
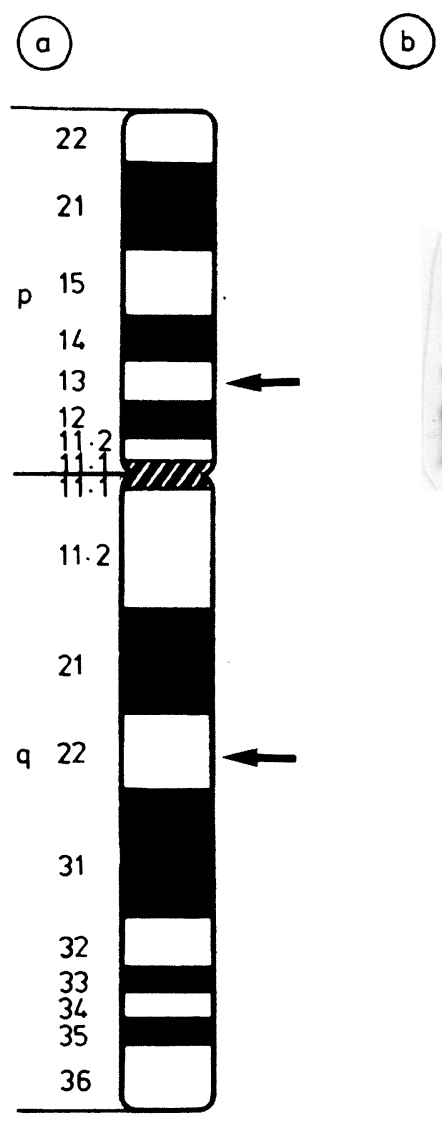

FIG 3(a) Diagram of $G$ banding pattern for normal chromosome 7; arrows indicate breakpoints. (Reproduced with permission from fig 9 in Harnden $D G$, Klinger $H P$, eds. ISCN 1985. An international system for human cytogenetic nomenclature. Basel: S Karger, 1985: 53. (b) Photomicrographs of chromosome 7 (right) containing pericentric inversion and of karyotypically unremarkable chromosome 7 (Giemsa, 500 band level). Arrowhead indicates p13 breakpoint, arrow indicates $q 22$ breakpoint.

\section{Discussion}

Type I collagen, a heterotrimer containing two $\alpha 1$ (I) 9 procollagen molecules and one $\alpha 2(\mathrm{I})$ procollagen $D$ molecule, constitutes approximately $95 \%$ of the collagen produced by osteoblasts. ${ }^{2}$ The gene for $\alpha 2$ (I) procollagen has been assigned to the long arm $\sigma$ of chromosome 7 at a site between bands q21 and $\tilde{N}$ $\mathrm{q} 22 .{ }^{3}$ This region may have been disrupted by the chromosomal inversion found in the infant and his mother.

Abnormal karyotypes have been reported in only $\stackrel{0}{\frac{0}{\Phi}}$ four other cases of OI. One infant, with features of $\stackrel{\mathcal{D}}{?}$ chondrodystrophy and a karyotype of $46, \mathrm{XY},-5$, 0 $-\mathrm{D}, \mathrm{t}(5 \mathrm{q}+; \mathrm{Dq}-)+; \operatorname{cen}+$, died during delivery; his tissues were so fragile that his limbs were avulsed. Because the karyotype was unbanded, the chromo- $\bar{\pi}$ somes involved could not be identified precisely. ${ }^{4}$ Another patient with severe disease who died in infancy had an unbanded karyotype of $46, \mathrm{XX}(92 \%) /$ 
$47, \mathrm{XX},+\mathrm{G}(8 \%) .{ }^{5}$ This low percentage mosaic state for a small acrocentric chromosome was probably coincidental. A karyotype of 46,XX,r(18)(p11q23), also probably an unrelated finding, was found in a third infant with lethal OI. ${ }^{6}$ Finally, a child with less severe disease had a karyotype of $46, \mathrm{XY}$, del(12) (p12p13). His father, who had a normal karyotype, also had moderately severe OI, indicating that OI in the child was probably unrelated to the partial deletion. ${ }^{7}$ We know of no previous report of OI associated with karyotypic abnormalities involving type I collagen gene sites.

Damage to one $\alpha 2$ (I) procollagen allele caused by the inversion might have contributed to disease in the infant if a mutation affecting the other allele was present. Such a mutation might either have occurred de novo or have been inherited from the father; compound heterozygosity for abnormalities in the $\alpha 2(I)$ procollagen gene, one of which was phenotypically recessive, has previously been reported in lethal 'broad boned' OI. ${ }^{8}$ It is also possible that a different de novo mutation caused OI in the infant by affecting one $\alpha 1$ (I) procollagen allele ${ }^{9}$ and that the observed inversion was not related to his disease. The risk that other children born to these parents will have OI is increased only if each parent is heterozygous for an $\alpha 2(\mathrm{I})$ procollagen gene abnormality. Attempts are now in progress to characterise $\alpha 2(\mathrm{I})$ procollagen genes and gene products in the parents for purposes of genetic counselling.

\section{References}

1 Schulz DM, Giordano DA, Schulz DH. Weights of organs of fetuses and infants. Arch Pathol 1962;74:244-50.

2 Auf'mholk B, Schwartz ER. Biochemical characterizations of human osteoblasts in culture. In: Dixon DA, Sarnat BG, eds. Normal and abnormal bone growth: basic and clinical research. New York: Alan R Liss, 1985: 210-4.

${ }^{3}$ McAlpine PJ, Shows TB, Miller RL, Pakstis AJ. The 1985 catalog of mapped genes and report of the nomenclature committee. HGM8. Cytogenet Cell Genet 1985;40:8-66.

${ }^{4}$ Richon J, Brunel G, Gilbenkrantz A, Masson JM. À propos d'un cas de fragilité tissulaire généralisée avec caryotype inédit chez un enfant mort au cours d'une extraction spectaculaire. Bull Fed Soc Gynecol Obstet Lang Fr 1971;23:503-5.

5 Ninatti GP, Patriarca PL. L'osteogenesi imperfetta (forma precoce di Vroelik). Osservazione clinica di un caso con studio biochemico e genetico. Minerva Pediatr 1968;20:1543-54.

${ }^{6}$ Marković S, Adžić S, Mijin K, Radojković Z, Lopičić L. Prstenasti khromosom $18 \mathrm{i}$ osteogenesis imperfecta u porodižhi u kojoj se javljaju spontani pobačaji. Srp Arh Celok Lek 1979;107:245-52.

7 Orye E, Craen M. Short arm deletion of chromosome 12. Report of two new cases. Humangenetik 1975;28:335-42.

${ }^{8}$ de Wet WJ, Pihlajaniemi T, Myers J, Kelly TE, Prockop DJ. Synthesis of a shortened pro- $\alpha 2$ (I) chain and decreased synthesis of pro- $\alpha 2(\mathrm{I})$ chains in a proband with osteogenesis imperfecta. $J$ Biol Chem 1983;258:7721-8.

${ }^{9}$ Chu M-L, Williams CJ, Pepe G, Hirsch JL, Prockop DJ, Ramirez F. Internal deletion in a collagen gene in a perinatal lethal form of osteogenesis imperfecta. Nature 1983;304:78-80.

Correspondence and requests for reprints to Dr A S Knisely, Department of Pathology and Laboratory Medicine, Women \& Infants' Hospital of Rhode Island, 101 Dudley Street, Providence, Rhode Island 02905-2401, USA.

\title{
Absence of a vagina and right sided adnexa uteri in the Waardenburg syndrome: a possible clue to the embryological defect
}

\author{
R M GOODMAN*, G OELSNER†, M BERKENSTADT*, AND D ADMON $\dagger$ \\ Departments of Medical Genetics* and Obstetrics and Gynecologyt, Chaim Sheba Medical Center, \\ Tel-Hashomer, and The Sackler School of Medicine, Tel-Aviv University, Ramat-Aviv, Israel.
}

SUMMARY An 18 year old single Jewish woman with the Waardenburg syndrome and absence of a vagina and right sided adnexa uteri is reported. Other congenital malformations associated with the Waardenburg syndrome are mentioned and it is postulated that they may be the result of an altered invasion of neurones or altered neurones in certain organ systems early in embryogenesis.
Over the years our group has described various congenital malformations associated with the Waardenburg syndrome. ${ }^{1-4}$ Recently, we had the opportunity to re-evaluate one of our patients that we had seen many years ago, and to our surprise we learned that she was born without a vagina and right adnexa uteri. The purpose of this brief report is to discuss the above observations in relation to other hypoplastic or aplastic congenital malformations seen in the Waardenburg syndrome.

\section{Case report}

An 18 year old single Jewish woman was referred to 